\title{
Quality of Different Papaya Cultivars Grown in the Greenhouse throughout the Year in Subtropical Regions
}

\author{
Esma GÜNEŞ ${ }^{1}$, Hatice Reyhan ÖZIYCI ${ }^{2}{ }^{\circledR}$, Hamide GÜBBÜK ${ }^{3^{*}}$ @ \\ ${ }^{1}$ Antalya Directorate of Provincial Agriculture and Forestry, Antalya, Turkey \\ ${ }^{2}$ Department of Gastronomy and Culinary Arts, School of Tourism, Antalya Bilim University, Antalya, Turkey \\ ${ }^{3}$ Department of Horticulture, Faculty of Agriculture, Akdeniz University, Antalya, Turkey \\ E-mail: gubbuk@akdeniz.edu.tr
}

Received: 26 August 2021; Revised: 1 December 2021; Accepted: 17 December 2021

\begin{abstract}
Harvest time is one of the factors affecting postharvest fruit quality. Under the subtropical condition, greenhouse cultivation allows a year-round harvest. However, the crop should meet the quality and the marketing criteria for overall customer satisfaction. This study aims to determine the impact of the harvest season on the quality characteristics of papaya fruit. For this purpose, two different cultivars (Sel-42 and Tainung) were grown in the greenhouse and harvested in the winter, the summer, the spring, and the autumn of two years. Sampling was carried out at the same visual maturity stage at each season. The two cultivars had soft fruit flesh almost throughout the year, although the fruit harvested in the winter had a better visual appeal in terms of color. Both fruit cultivars harvested in the autumn had higher soluble solids and lower acidity. The highest concentrations of total phenolic content and L-ascorbic acid were observed in the spring and summer season harvested fruits although there was no significant difference between those $(\mathrm{P}>0.05)$. It was concluded that the growth in the greenhouse minimizes the harvest season effects on papaya fruit quality. Thus, greenhouse cultivation is recommended for a higher quality product, especially in a subtropical climate.
\end{abstract}

Keywords: papaya fruit, seasonal changes, greenhouse crop, harvest season, Sel-42, Tainung, phytochemistry

\section{Abbreviations}

AA: L-ascorbic acid

SS: Soluble Solids

TA: Titratable Acidity

TPC: Total Phenolic Content

\section{Introduction}

Cultivars, harvest season, soil composition, and agrotechnical procedures are among the factors affecting the physicochemical properties and fruit's quality [1-4]. It is essential to control the crop cultivation conditions in order to

Copyright (C2021 Hamide GÜBBÜK, et al.

DOI: https://doi.org/10.37256/fse.3120221117

This is an open-access article distributed under a CC BY license

(Creative Commons Attribution 4.0 International License)

https://creativecommons.org/licenses/by/4.0/ 
provide customers with year-round production of high-quality fruit. In the case of papaya, greenhouse cultivation seems to be effective in achieving this goal [5]. Cultivation in a controlled environment provides adequate temperatures needed also to prevent the incidence of Papaya Ringspot Virus (PRSV) [6].

Various parts of papaya are very rich in nutritional compounds [7]. The fruit contains many nutrients such as phenols, alkaloids, flavonoids, tannins, Vitamin A, Vitamin C, niacin, folic acid, thiamine, riboflavin, and also rich in $\beta$-carotene $[8,9]$. The chemical composition of the fruit changes during the stages of fruit development. While moisture content is not changed significantly, dry matter, crude fiber, ash, protein, fat, and carbohydrate contents of the fruit decreases during ripening $[10,11]$. Papaya fruit is very susceptible to postharvest losses due to its climacteric nature [12]. Thus, the ripening conditions affect the quality and the nutritional composition of the fruit. Previous studies were carried out to identify the interaction between ripening conditions and fruit quality examining various cultivars and various ripening stages [11, 13-17]. However, to the best of our knowledge, there has been no study investigating the effect of the harvest seasons on the physicochemical properties of the papaya fruit at harvest maturity in greenhouse.

Greenhouse cultivation is important to allow the production of fruit and vegetables throughout the year by protecting plants against environmental changes. Therefore, the aim of this study was to investigate the physicochemical properties of papaya cultivars at the same harvest maturity grown in a greenhouse at different harvest seasons. Two papaya cultivars (Sel-42 and Tainung) were harvested at the same visual maturity stage at all four seasons. The traits: fruit color, flesh firmness, soluble solids/titratable acidity ratio, total phenolic content, and L-ascorbic acid were analyzed.

\section{Materials and methods}

\subsection{Materials}

F1 hybrid papaya cultivars of Sel-42 and Tainung were used in the experiments. All analytical chemicals were obtained from Sigma-Aldrich (St Louis, MO, USA). For chromatographic analysis, deionized water of $18.2 \mathrm{MOhm}$ resistivities, purified with a Milli-Q system (Millipore, Bedford, USA) was used.

\subsection{Growth conditions and harvest time}

This research was conducted between 2009 and 2011 in a $1000 \mathrm{~m}^{2}$ plastic greenhouse (Latitude: $\mathrm{N} 36^{\circ} 54028$ ', Longitude: E $30^{\circ} 38-810^{\prime}$, Altitude $38 \mathrm{~m}$ ) belonging to Seed Research and Development Center of Akdeniz University. The papaya plants were transplanted on the $28^{\text {th }}$ of March 2009 at $2.5 \mathrm{~m}$ intervals between the plants on a line $(1.8 \mathrm{~m}$ intervals between the lines inside of the greenhouse). A drip irrigation system and a fertilization program were applied. The moisture content, electrical conductivity, and $\mathrm{pH}$ values of the soil were measured with a tensiometer on the next day of drip irrigation in the greenhouse. Irrigation and fertilization were done by considering these measurements and climatic values. The fertilization program was based on soil analysis. The fertilization was applied in 5-6-day periods according to the water requirement of the soil. After drip irrigation, approximately $350 \mathrm{~g} \mathrm{~N}, 225 \mathrm{~g} \mathrm{P}_{2} \mathrm{O}_{5}, 550$ $\mathrm{g} \mathrm{K}_{2} \mathrm{O}, 25 \mathrm{~g} \mathrm{MgO}$ and $5 \mathrm{~g} \mathrm{CaO}$ were applied during the vegetation period. Fertilization was based on the ratio of 1:3:1 (Nitrogen-Phosphorus-Potassium) in the first three applications after planting, followed by the ratio of 2:1:3 until fruit development and finally based on the ratio of 3:1:6 during fruit development. During the cultivation, a mini meteorology station (HOBO, Tartes Agri. Ind. Comm. Ltd., Turkey) was placed in the greenhouse to record the temperature and Relative Humidity (RH) from April 2009 to October 2011. The measurements were taken hourly.

The papaya fruits were harvested in the months of January, April, July, and October representing the seasons of winter, spring, summer, and autumn during 2010 and 2011. Harvesting the fruit at the full ripeness stage leads to short shelf life. Therefore, commercial harvest is generally carried out when the peel (exocarp) color turns yellow (from dark or light green), approaching one-quarter to one-half depending on the distance to the market [18]. In the study, the fruits were harvested at the same ripening stage (one-third yellow on fruit peel; Ripening Stage-3 [RST3]) [19].

\subsection{Methods}

\subsubsection{Peel color}

A colorimeter with light source D65 and $10^{\circ}$ observer (Minolta Chroma Meter, CR300, Minolta, Osaka, Japan) 
were used to assess the peel color of harvested papaya fruit [20]. The triplicate measurements of $L^{*}, a^{*}$, and $b^{*}$ values were taken around the fruit equator. The $a^{*}$ and $b^{*}$ values were used to calculate hue angle $\left[h^{\circ}=\arctan \left(b^{*} / a^{*}\right)\right]$ and chroma values $\left(C=\left(a^{*^{2}}+b^{*^{2}}\right)^{0.5}\right)$ [21]. $L$ is defined as lightness (luminosity) within the range of 0-100 (0: black, 100: white) [22]; $h^{\circ}$ (Hue angle) is defined as what the color is (red at $0^{\circ}$, yellow at $90^{\circ}$, green at $180^{\circ}$, blue at $270^{\circ}$ ); $C^{*}$ (Chroma) is defined as the intensity or depth of color [23]. The higher the $C^{*}$ values, the higher the color density of the samples perceived [24].

\subsubsection{Flesh firmness}

The firmness of the papaya fruit flesh was measured by Effegi penetrometer (Model FT 327, EFFEGI, Milan, Italy) fitted with a $7.9 \mathrm{~mm}$ Effegi probe. The fruit was peeled then measurements were taken from three different surface points of each fruit. The average values of the measurements were expressed as a Pa unit.

\subsubsection{Calculation of ripening index (SS/TA)}

Ripening Index (SS/TA) was calculated by dividing Soluble Solids (SS) to Titratable Acidity (TA). The juice of the papaya fruit was extracted with a juicer and subjected to SS analysis using a hand refractometer (ATC HT113, China) and TA analysis was performed using a $\mathrm{pH}$ meter (Thermo Scientific ${ }^{\mathrm{TM}}$ Orion $^{\mathrm{TM}}$ 3-Star, USA) and $0.1 \mathrm{~N} \mathrm{NaOH}$ solution). Soluble solids and TA values were expressed as a percent and citric acid equivalent ( $\mathrm{g}$ citric acid $100 \mathrm{~g}^{-1}$ ), respectively [25].

\subsubsection{Determination of Total Phenolic Content (TPC)}

Total Phenolic Content (TPC) was determined with Folin-Ciocalteu's phenol reagent with reference to the method of Slinkard and Singleton [26]. Accordingly, all fruit samples and gallic acid standards were dissolved in 50\% methanol using the equation obtained from the standard. Then $0.5 \mathrm{ml}$ of sample, $2.5 \mathrm{~mL}$ of Folic-Ciocalteu's phenol reagent, and 7.5 $\mathrm{ml}$ of $\mathrm{Na}_{2} \mathrm{CO}_{3}$ solution $(20 \%$, w/v) were put in a tube and mixed using a vortex. All samples were kept in the dark for 2 hours. Then the absorbance values of the samples were measured at $750 \mathrm{~nm}$ using a UV-VIS spectrophotometer (Thermo Scientific Evolution 201 UV-VIS Spectrophotometer, USA). All results were expressed as Gallic Acid Equivalent (GAE) per $100 \mathrm{~g}$ sample by using a calibration curve prepared with a series of gallic acid standards $\left(0-200 \mathrm{mg} \mathrm{L}^{-1}\right)$.

\subsubsection{Determination of L-ascorbic acid}

The concentration of L-ascorbic acid was determined according to Karhan, Aksu [27]. Sixty g of the edible fruit was transferred to $250 \mathrm{~mL}$ of the volumetric flask containing $10^{-6} \mathrm{M}$ ethylenediaminetetraacetic acid (EDTA), $10^{-7}$ M diethyldithiocarbamic acid, and 6\% HPO3. The mixture was homogenized at 24,000 rpm with an Ultra-Turrax homogenizer (IKA T8, Germany), then centrifuged at 3,000 rpm for 20 minutes. The supernatant was first filtered through Whatman No: 42 filter paper then through a $0.45 \mu \mathrm{m}$ membrane filter. Quantification was calculated by an external standard method using the L-ascorbic acid standard.

The HPLC system consisted of Shimadzu LC-20 AD Solvent Delivery System (Japan) equipped with the column

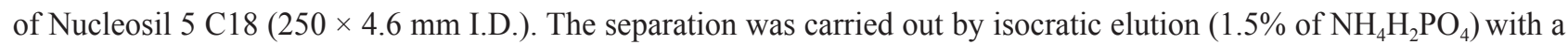
flow rate of $0.9 \mathrm{ml} \mathrm{min}^{-1}$. The column temperature was ambient. The eluate was detected using a Shimadzu DAD-M20 A photodiode array detector set at $264 \mathrm{~nm}$. The injection volume was $20 \mu \mathrm{L}$.

\subsubsection{Statistical analysis}

Per each harvest period representing the different seasons, 5 fruits were harvested from every plant with three replications $(\mathrm{N}=15$ per each season). Statistical analysis was examined by the One-Way Analysis of Variance (One-Way ANOVA) method followed by Tukey's multiple range test. Statistical significance was tested at $\mathrm{P} \leq 0.05$. All analyses were carried out with OriginPro 2019b statistical package (OriginLab Corporation, 9.6.5.169). 


\section{Results}

During the cultivation of the papaya plants in the greenhouse, the lowest and highest temperature and $\mathrm{RH}$ values as the average of measured years $(2009-2011)$ were $13.3{ }^{\circ} \mathrm{C} \pm 1.16{ }^{\circ} \mathrm{C}$ and $30.30{ }^{\circ} \mathrm{C} \pm 0.45{ }^{\circ} \mathrm{C}$ with $57.79 \% \pm 9.52 \%$ and $80.68 \% \pm 4.75 \%$, respectively (Figure 1 ).

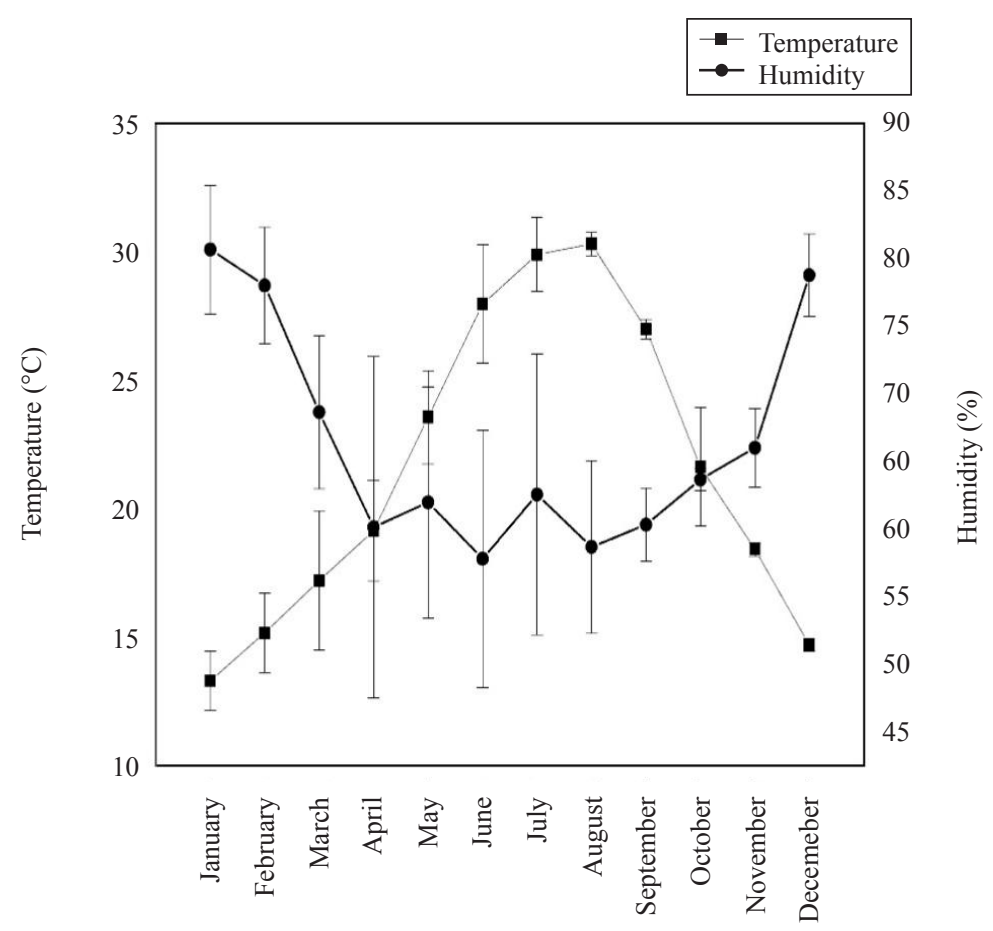

Figure 1. Climatic data of papaya cultivated in greenhouse [Values are the average of years (from April 2009- to October 2011) of measurement]

These climatic data were used to interpret the changes in chemical and organoleptic properties of the fruits in the study. Because it is stated that especially the cultivation in subtropical climate conditions, where the daily temperature decreases below $11^{\circ} \mathrm{C}$, harms the fruit development [28].

\subsection{Peel color}

There was no difference in the peel color of the harvested fruit. However, in general, the fruit harvested in the colder seasons (autumn and winter and even the spring) had a more yellow color. On the other hand, although $C^{*}$ values indicating the purity, or the density of the yellow color was not significantly different between the various harvest seasons $(\mathrm{P}>0.05)$, the samples harvested in the summer and autumn seasons had higher values $(\mathrm{P}<0.05$; Figure 2$)$.

No significant difference between the two cultivars in terms of hue angle, chroma, and lightness were found $(\mathrm{P}<$ 0.05). While the highest $h^{\circ}$ value (79.71 ${ }^{\circ}$, higher yellow) was observed in Sel-42 fruit cultivar harvested in the winter season, the lowest $h^{\circ}$ values $\left(56.92^{\circ}\right.$ for $\mathrm{Sel}-42 ; 58.54^{\circ}$ for Tainung) were observed for both fruit varieties in the summer season (Figure 2). In terms of lightness, the Sel-42 harvested in autumn ( $L: 65.68)$ had the highest value among all. The fruit of both cultivars harvested in the summer had lower $L$ values.

\subsection{Flesh firmness}

The flesh firmness of Sel-42 significantly decreased during the seasonal transition from winter to summer then increased in autumn. On the other hand, the flesh firmness of Tainung decreased steadily from the winter to autumn period (Figure 3). 

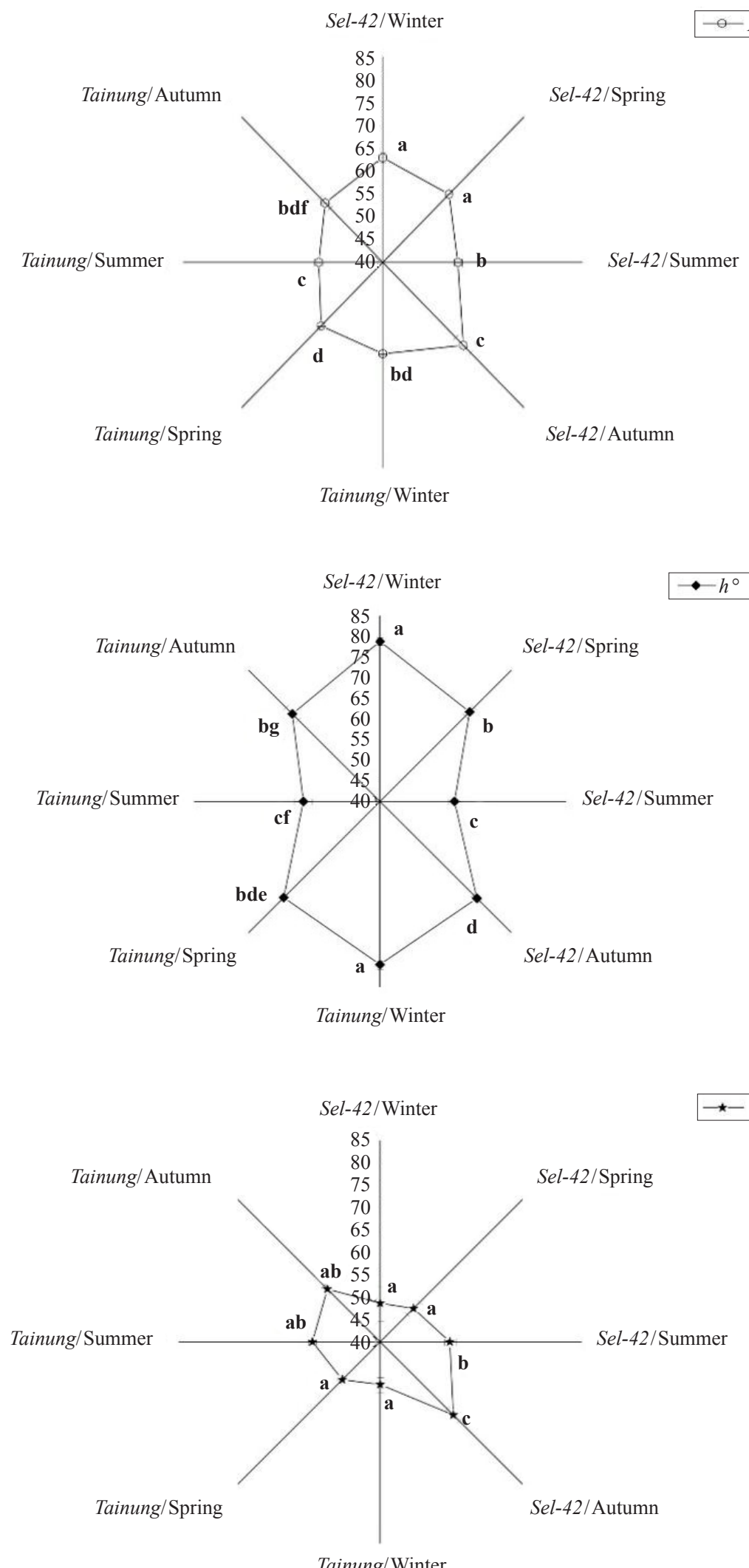

Tainung/Winter

Figure 2. Color $\left(L, C, h^{\circ}\right)$ values of Sel-42 and Tainung papayas (Different letters represent significant differences at $\mathrm{P}<0.05$ ) 


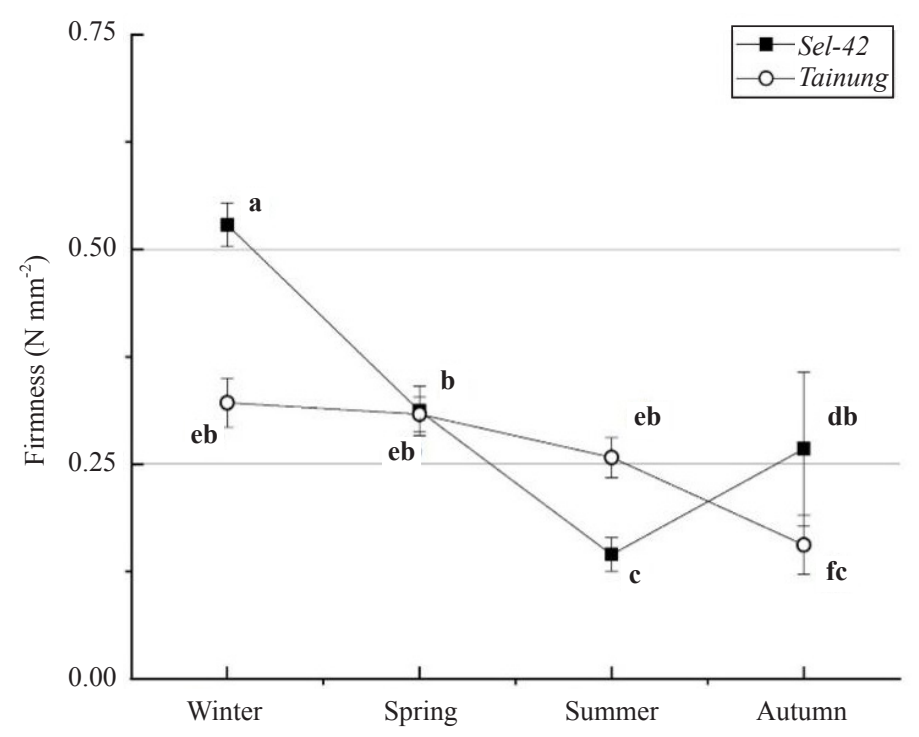

Figure 3. Flesh firmness of Sel-42 and Tainung papayas (Different letters represent significant differences at $\mathrm{P}<0.05$ )

Comparison of both cultivars showed that the Sel-42 was generally softer, while Tainung cultivated in autumn and Sel-42 cultivated in the summer have the same firmness $(\mathrm{P}>0.05)$. The highest firmness value $\left(0.53 \mathrm{~N} \cdot \mathrm{mm}^{-2}\right)$ was observed in Sel-42 papaya fruit harvested in the winter season among all. The fruit for this cultivar harvested in summer had the softest flesh compared to the other seasons (Figure 3).

\subsection{Chemical ripening index (SS/TA)}

Soluble Solids (SS) and Total Acidity (TA) values of all samples were between $8.48 \% \pm 0.48-11.71 \% \pm 0.23$ and $0.094 \pm 0.006-0.12 \pm 0.002 \mathrm{~g}$ citric acid $100 \mathrm{~g}^{-1}$ (Table 1).

Table 1. Soluble Solids (SS) and Titratable Acidity (TA) values of Sel-42 and Tainung papaya fruits

\begin{tabular}{cccc}
\hline Papaya cultivar & Season & SS $(\%)^{*}$ & TA $\left(\mathrm{g} \text { citric acid } 100 \mathrm{~g}^{-1}\right)^{*}$ \\
\hline Sel-42 & Winter & $9.40^{\mathrm{a}} \pm 0.83$ & $0.11^{\mathrm{a}} \pm 0.01$ \\
& Summer & $8.90^{\mathrm{a}} \pm 0.83$ & $0.13^{\mathrm{b}} \pm 0.00$ \\
& Autumn & $10.68^{\mathrm{b}} \pm 0.25$ & $0.10^{\mathrm{a}} \pm 0.00$ \\
Tainung & $11.71^{\mathrm{c}} \pm 0.24$ & $0.10^{\mathrm{a}} \pm 0.01$ \\
& Winter & $8.48^{\mathrm{a}} \pm 0.48$ & $0.10^{\mathrm{a}} \pm 0.01$ \\
& Spring & $8.70^{\mathrm{a}} \pm 0.23$ & $0.12^{\mathrm{a}} \pm 0.00$ \\
& Summer & $8.81^{\mathrm{a}} \pm 0.44$ & $0.11^{\mathrm{a}} \pm 0.01$ \\
& Autumn & $9.87^{\mathrm{b}} \pm 0.35$ & $0.09^{\mathrm{a}} \pm 0.01$ \\
\hline
\end{tabular}

*: Different letters within the same column represents significant differences at $\mathrm{P}<0.05$

Statistical analysis showed no significant difference between Sel-42 harvested in the summer and autumn seasons and Tainung harvested in the autumn season $(\mathrm{P} \leq 0.05)$. This could be due to the high ratio of sugar to acidity, making 
the fruit more palatable. Among all samples harvested at different seasons; both papaya cultivars harvested in autumn had the highest SS values (11.71\% for Sel-42 and 9.87\% for Tainung, Figure 4).

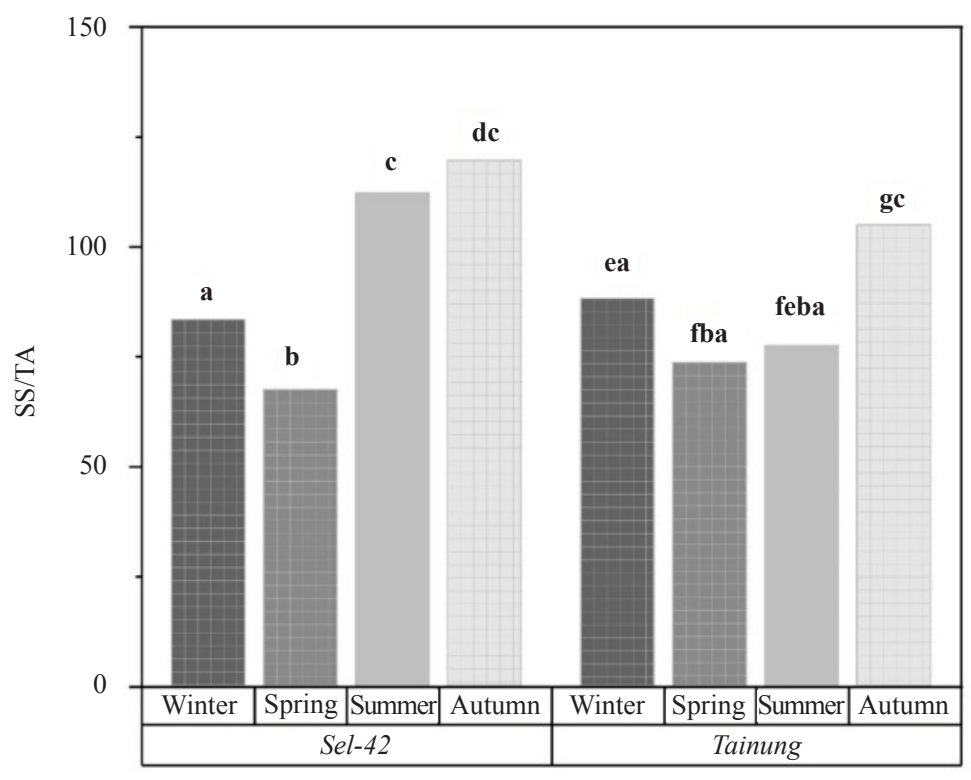

Figure 4. Ripening index of Sel-42 and Tainung papayas (Different letters represent significant differences at $\mathrm{P}<0.05$ )

\subsection{Total Phenolic Content (TPC)}

Total phenolic contents of Sel-42 and Tainung did not significantly change except the highest TPC values observed in Sel-42 papayas harvested in spring (137.73 mg GAE $100 \mathrm{~g}^{-1}$ ) and summer (144.43 mg GAE $100 \mathrm{~g}^{-1}$ ) seasons (Table 2, P > 0.05). Tainung papayas had relatively lower TPC values (93.33-97.27 mg GAE $\left.100 \mathrm{~g}^{-1}\right)$ than Sel-42 papayas (102.25-144.43 mg GAE $\left.100 \mathrm{~g}^{-1}\right)$.

Table 2. Total Phenolic Content (TPC) and L-ascorbic acid (AA) values of Sel-42 and Tainung papaya fruits*

\begin{tabular}{cccc}
\hline Papaya cultivar & Season & AA $\left(\mathrm{mg} \mathrm{AA} 100 \mathrm{~g}^{-1}\right)$ & TPC $\left(\mathrm{mg}\right.$ GAE $\left.100 \mathrm{~g}^{-1}\right)$ \\
\hline Sel-42 & Winter & $61.86^{\mathrm{a}} \pm 5.15$ & $102.25^{\mathrm{a}} \pm 9.66$ \\
& Spring & $86.77^{\mathrm{b}} \pm 19.08$ & $137.73^{\mathrm{b}} \pm 24.88$ \\
& Summer & $85.13^{\mathrm{b}} \pm 17.67$ & $144.43^{\mathrm{bc}} \pm 22.99$ \\
& Autumn & $76.32^{\mathrm{a}} \pm 12.56$ & $114.88^{\mathrm{a}} \pm 11.93$ \\
Tainung & Winter & $63.88^{\mathrm{a}} \pm 1.09$ & $93.33^{\mathrm{a}} \pm 3.37$ \\
& Spring & $68.08^{\mathrm{ab}} \pm 2.71$ & $92.95^{\mathrm{a}} \pm 7.10$ \\
& Summer & $67.81^{\mathrm{ab}} \pm 2.62$ & $93.75^{\mathrm{a}} \pm 2.39$ \\
& Autumn & $64.86^{\mathrm{a}} \pm 2.67$ & $97.27^{\mathrm{a}} \pm 11.58$ \\
\hline
\end{tabular}

*: Different letters within the same column represents significant differences at $\mathrm{P}<0.05$ 


\subsection{L-ascorbic acid}

L-ascorbic acid (AA) content followed the same trend as TPC value for the cultivars Sel-42 and Tainung depending on the seasons (Table 2). Accordingly, the highest AA values were obtained in Sel-42 harvested in spring (86.77 mg AA $\left.100 \mathrm{~g}^{-1}\right)$ and summer ( $\left.85.13 \mathrm{mg} \mathrm{AA} 100 \mathrm{~g}^{-1}\right)$, although there was no statistically significant difference between the two seasons $(\mathrm{P}>0.05)$. On the other hand, seasonal changes did not affect the AA content of Tainung grown in the greenhouse $(\mathrm{P}>0.05)$. In the winter and autumn seasons, Sel-42 papaya had similar AA contents as Tainung harvested throughout the year $(\mathrm{P}>0.05)$. While there was no significant seasonal difference in terms of ascorbic acid in tainung papaya harvested in different seasons, the highest concentrations were reached in the samples harvested in spring and summer in Sel-42 variety (Table 2). Change in AA concentration may be due to the exact ripening stage at which the harvest takes place or due to different cultivars [29].

\section{Discussion}

\subsection{Physical characteristics of papaya fruit}

Skin color is one of the important attributes to define fruit ripening. The parameters indicating the color change through this period. For example, the lightness $(L)$ of the skin part of papaya decreases as the fruit ripens [30]. Schweiggert, Steingass [31] also reported $L, C, h^{\circ}$ color values indicating bright yellow color formation during papaya ripening on tree as 61.2, 61.2 and 77.2 ${ }^{\circ}$, respectively. The $L$ and $h^{\circ}$ values of the harvested fruits were similar to the values reported by Schweiggert, Steingass [31], but the authors recorded higher $C$ values than the results of this study. This difference might be due to the Costa Rican hybrid "Pococi" they used and their experiment condition of an open field. Results of this study indicate that especially in colder climates, the yellowness of the fruit increases.

Flesh firmness is an important indicator for fruit quality and should be maintained during postharvest storage and shelf-life period [32]. Very low firmness values (as the lowest $0.14 \pm 0.019 \mathrm{~N} . \mathrm{mm}^{-2}$ and the highest $0.53 \pm 0.025$ N.mm ${ }^{-2}$ ) were observed for Sel-42 and Tainung compared to those obtained by Bron and Jacomino [14]; Pinillos, López [33] that reported higher firmness values than this study for papaya fruit in greenhouse cultivation at various harvesting periods. This difference may be due to the different papaya cultivars (Golden and BH-65 papayas) that were chosen for their experiments. In comparing the firmness of papaya in subtropical climate and greenhouse cultivation conditions, although the sample papaya species reached the softest level in different seasons (Tainung: Autumn, Sel-42: Summer; P $<0.05)$, the hardness of the samples harvested at the same maturity level remained almost the same throughout the year $(\mathrm{P}$ $>0.05)$.

\subsection{Chemical characteristics of papaya fruit}

Sugars and organic acids can be affected by seasonal dynamics [34]. They are important components responsible for the flavor of papaya thus affecting the sensory attributes of the product [35]. Ripening index (Sugar/Acid ratio) is considered as the best objective measurement reflecting consumers' perception thus it is highly important to be assessed [36]. Although Kader [37] indicated that the suggested minimum for SS level in papayas being $11.5 \%$ for the total SS level, Nakasone and Paull [18] are a little bit more precise indicating as acceptable an average of $11.5 \%$ for any lot of papayas, provided that no more than $5 \%$ by count of the fruit in the lot have SS less than $10.5 \%$. Thus, it is thought that Sel-42 harvested in the autumn season in this study (SS value of $11.71 \%$ ) may be preferred by the consumers (see Table 1). However, it may be also possible that the Tainung harvested in the autumn can also be sensorially accepted in terms of ripening index due to its relatively low acidity $(0.094 \pm 0.006)$ and soluble solids close to the minimum acceptable level $(9.87 \pm 0.35)$, values similar to literature findings [38] for fully ripe Tainung $\left(10.70 \%\right.$ for SS, $0.085 \mathrm{~g} \mathrm{ml}^{-1}$ for TA, SS/TA: 141.27). Generally, there is a negative correlation between sugar content and fruit firmness during the ripening period [39]. This is due to the accumulation of sugars in fruit tissues. Thus, softening occurs with an increasing concentration of sugars [40]. This agrees with the obtained results in the current study. In fact, there was a moderately negative correlation $(\mathrm{r}=-0.30)$ between sugar and firmness values means that the papaya fruits with high sugar content had lower firmness (Figure 3 and 4).

The value of TPC (92.95 mg GAE $100 \mathrm{~g}^{-1}$ ) of Tainung harvested in the spring (April) was higher than reported by Özkan, Gübbük [41]. These authors also analyzed the TPC content of Tainung harvested in May at a commercially 
ripe stage of one-fourth yellow color in the peel. They reported a TPC value of $42 \mathrm{mg}$ GAE $100 \mathrm{~g}^{-1}$. This difference might be due to the different ripening stages for harvesting (in this study, one-third yellow color was the time of harvest). In addition, the climate and the cultivation conditions may have affected the chemical composition of the fruit. Several studies have tested the effect of the ripening stage on the physicochemical properties and especially TPC $[17,42]$. However, since in this study, the physicochemical properties of the fruit harvested at various seasons at approximately the same harvest maturity level were examined, it was not possible to precisely compare our results with the aforementioned studies, especially those in which, the harvest season of the fruit was not clearly stated.

Kelebek, Selli [43] compared the chemical compositions of Sel-42 and Tainung that were harvested in May at the commercially ripe stage (one-fourth yellow color in fruit peel) and reported that Sel-42 had a higher AA concentration (71.70 mg AA $100 \mathrm{~g}^{-1}$ ) than Tainung $\left(67.30 \mathrm{mg} \mathrm{AA} 100 \mathrm{~g}^{-1}\right)$. This result agreed with the findings of this study.

\section{Conclusion}

This study shows that under the condition of this experiment the papaya fruit harvested in colder seasons (approximate measured climatic values were $13-22{ }^{\circ} \mathrm{C}, 64-81 \% \mathrm{RH}$, Figure 1) had better physical properties (bright, yellow color, soft tissue texture) for the consumers than those harvested in warmer weather in the same location. Papaya cultivars especially harvested in autumn had higher sugar content (soluble solids) and relatively lower acidity. The sugar/Acid ratio is an important parameter of fruit sensory attraction. Accumulation of total phenolic content and L-ascorbic acid in the fruit tissues was not affected by the seasonal harvest.

Considering the results obtained from this study, it can be concluded that there is the possibility to produce papaya fruit in the subtropical areas of Turkey. However, further studies should be implemented for the evaluation of fruit yield/ quality characteristics and consumer acceptance by growing different cultivars of this fruit so that a crop with high economic return for the farmers would be suggested.

\section{Acknowledgements}

This study was financially supported by the Scientific Research Projects Coordination Unit of Akdeniz University (Project Number: 2009.03.0121.006), Antalya, Turkey. Authors thank to Prof. Dr. Ahmed Ait-Oubahou (Agronomic and Veterinary Institute Hassan II, Morocco), Dr. Mam Singh (Principal Scientist at Centre for Protected Cultivation Technology, New Delhi Area, India) and Dr. Tomas Ayala-Silva (USDA/ARS, Tropical Agriculture Research Station, Mayaguez, Puerto Rico) for their valuable contribution to the technical revision of this article.

\section{Conflict of interest}

The authors declare that they have no known competing financial interests or personal relationships that could have appeared to influence the work reported in this paper.

\section{References}

[1] Díaz-Mula HM, Zapata PJ, Guillén F, Castillo S, Martínez-Romero D, Valero D, et al. Changes in physicochemical and nutritive parameters and bioactive compounds during development and on-tree ripening of eight plum cultivars: a comparative study. Journal of the Science of Food and Agriculture. 2008; 88(14): 2499-2507.

[2] Kühne F, Allan P. Seasonal variations in fruit growth of Carica papaya L. Agroplantae. 1970; 2(3): 99-104.

[3] Moretti C, Mattos L, Calbo A, Sargent S. Climate changes and potential impacts on postharvest quality of fruit and vegetable crops: a review. Food Research International. 2010; 43(7): 1824-1832.

[4] Storey R, Treeby M. Seasonal changes in nutrient concentrations of navel orange fruit. Scientia Horticulturae. 2000; 84(1-2): 67-82. 
[5] Reddy P, Gowda V. Influence of greenhouse cultivation on fruit quality of 'Red Lady' papaya. Acta Horticulturae. 2014; 1024: 109-114.

[6] Galán Saúco V, Hernández EP. Greenhouse cultivation In: Mitra S (Ed.). The Papaya: Botany, Production and Uses. Wallingford UK: CAB International; 2020. p. 226-236.

[7] Pinnamaneni R. Nutritional and medicinal value of papaya (Carica papaya Linn.). World Journal of Pharmacy and Pharmaceutical Sciences. 2017; 6(8): 2559-2578.

[8] Imaga NA, Gbenle GO, Okochi VI, Adenekan S, Duro-Emmanuel T, Oyeniyi B, et al. Phytochemical and antioxidant nutrient constituents of Carica papaya and Parquetina nigrescens extracts. Scientific Research and Essays. 2010; 5(16): 2201-2205.

[9] Nwofia GE, Ojimelukwe P, Eji C. Chemical composition of leaves, fruit pulp and seeds in some Carica papaya (L) morphotypes. International Journal of Medicinal and Aromatic Plants. 2012; 2(1): 200-206.

[10] Cámara M, Diez C, Torija M. Changes during ripening of papaya fruit in different storage systems. Food Chemistry. 1993; 46(1): 81-84.

[11] Chukwuka K, Iwuagwu M, Uka UJIJoP. Evaluation of nutritional components of Carica papaya L. at different stages of ripening. IOSR Journal of Pharmacy and Biological Sciences. 2013; 6(4): 13-16.

[12] Fabi JP, Cordenunsi BR, de Mattos Barreto GP, Mercadante AZ, Lajolo FM, Oliveira do Nascimento JR. Papaya fruit ripening: response to ethylene and 1-methylcyclopropene (1-MCP). Journal of Agricultural Food Chemistry. 2007; 55(15): 6118-6123.

[13] Almora K, Pino JA, Hernández M, Duarte C, González J, Roncal E. Evaluation of volatiles from ripening papaya (Carica papaya L., var. Maradol roja). Food Chemistry. 2004; 86(1): 127-130.

[14] Bron IU, Jacomino APJBJoPP. Ripening and quality of 'Golden' papaya fruit harvested at different maturity stages. Brazilian Journal of Plant Physiology. 2006; 18(3): 389-396.

[15] Pinillos V, Guerrero J, Salinas I, Cuevas J, Hueso JJ. Fruit quality characterization and harvest maturity index of three papaya cultivars grown in greenhouses in south-east Spain. Acta Horticulturae. 2019; 1250: 173-178.

[16] Wills R, Widjanarko S. Changes in physiology, composition and sensory characteristics of Australian papaya during ripening. Australian Journal of Experimental Agriculture. 1995; 35(8): 1173-1176.

[17] Zuhair R, Aminah A, Sahilah A, Eqbal D. Antioxidant activity and physicochemical properties changes of papaya (Carica papaya L. cv. Hongkong) during different ripening stage. International Food Research Journal. 2013; 20(4): 1653.

[18] Nakasone HY, Paull RE. Tropical Fruits. Wallingford, UK: CAB International; 1998.

[19] Barragán-Iglesias J, Méndez-Lagunas LL, Rodríguez-Ramírez J. Ripeness indexes and physicochemical changes of papaya (Carica papaya L. cv. Maradol) during ripening on-tree. Scientia Horticulturae. 2018; 236: $272-278$.

[20] Ayala-Silva T, Gubbuk H, Winterstein M, Mustiga G. Pomological and physicochemical characterization of Tamarindus indica (tamarind) grown in Florida. The Journal of Agriculture of the University of Puerto Rico. 2016; 100(2): 141-154.

[21] McGuire RG. Reporting of objective color measurements. HortScience. 1992; 27(12): 1254-1255.

[22] Castricini A, Dias MSC, Rodrigues MGV, Oliveira P. Quality of organic banana produced in the semiarid region of Minas Gerais, Brazil. Revista Brasileira de Fruticultura. 2017; 39(2). Available from: doi: 10.1590/0100-29452017813.

[23] Hammond DA. Analysis of soft drinks and fruit juices In: Ashurst PR, editor. Chemistry and Technology of Soft Drinks and Fruit Juices. UK: John Wiley \& Sons, Ltd.; 2016. p. 231-289.

[24] Granato D, Masson ML. Instrumental color and sensory acceptance of soy-based emulsions: a response surface approach. Ciência e Tecnologia de Alimentos. 2010; 30(4): 1090-1096.

[25] Cemeroğlu B. Gida Analizleri (Food Analyses). Ankara: Gıda Teknolojisi Derneği Yayınları; 2007. p. 535.

[26] Slinkard K, Singleton VL. Total phenol analysis: automation and comparison with manual methods. American Journal of Enology. 1977; 28(1): 49-55.

[27] Karhan M, Aksu M, Tetik N, Turhan I. Kinetic modeling of anaerobic thermal degradation of ascorbic acid in rose hip (Rosa canina L) pulp. Journal of Food Quality. 2004; 27(5): 311-319.

[28] Allan P. Carica papaya responses under cool subtropical growth conditions. Acta Horticulturae. 2002; 575: 757-763.

[29] Wall MM. Ascorbic acid, vitamin A, and mineral composition of banana (Musa sp.) and papaya (Carica papaya) cultivars grown in Hawaii. Journal of Food Composition and Analysis. 2006; 19(5): 434-445. Available from: doi: 10.1016/j.jfca.2006.01.002.

[30] Basulto FS, Duch ES, Espadas F, Plaza RD, Saavedra AL, Santamaría JM. Postharvest ripening and maturity 
indices for maradol papaya. Interciencia. 2009; 34(8): 583-588.

[31] Schweiggert RM, Steingass CB, Mora E, Esquivel P, Carle R. Carotenogenesis and physico-chemical characteristics during maturation of red fleshed papaya fruit (Carica papaya L.). Food Research International. 2011; 44(5): 1373-1380.

[32] Ferguson IB, Boyd LM. Inorganic nutrients and fruit quality. In: Knee M (Ed.). Fruit Quality and its Biological Basis. UK Sheffield Academic Press Ltds; 2003. p. 17-38.

[33] Pinillos V, López A, Salinas I, Hueso J, Cuevas J. Effects of stage of harvest maturity and season on fruit quality of papaya cultivated in southeast Spain greenhouses. Acta Horticulturae. 2018; 1194: 143-148.

[34] Sturm K, Stampar F. Seasonal variation of sugars and organic acids in apple (Malus domestica Borkh.) in different growing systems. Phyton (Horn). 1999; 39(3): 91-96.

[35] Wijaya H, Chen F. Flavour of papaya (Carica papaya L.) fruit. Biotropia. 2013; 20(1): 50-71.

[36] Jayasena V, Cameron I. ${ }^{\circ}$ Brix/acid ratio as a predictor of consumer acceptability of Crimson Seedless table grapes. Journal of Food Quality. 2008; 31(6): 736-750.

[37] Kader AA. Fruit maturity, ripening, and quality relationships. International Symposium Effect of Pre-\& Postharvest factors in Fruit Storage. 1997; 485.

[38] Luz LN, Vettorazzi JC, Santa-Catarina R, Barros FR, Barros G, Pereira MG, et al. Sensory acceptance and qualitative analysis of fruits in papaya hybrids. Anais da Academia Brasileira de Ciências. 2018; 90(4): 36933703.

[39] Moirangthem K, Tucker G. How do fruits ripen. Frontiers for Young Minds. 2018; 6: 1-7.

[40] Selvaraj Y, Pal D, Subramanyam M, Iyer C. Changes in the chemical composition of four cultivars of papaya (Carica papaya L.) during growth and development. Journal of Horticultural Science. 1982; 57(1): 135-143.

[41] Özkan A, Gübbük H, Güneş E, Erdoğan A. Antioxidant capacity of juice from different papaya (Carica papaya L.) cultivars grown under greenhouse conditions in Turkey. Turkish Journal of Biology. 2011; 35(5): 619-625.

[42] Addai ZR, Abdullah A, Mutalib SA. Influence of ripening stages on antioxidant properties of papaya fruit (Carica papaya L.). AIP Conference Proceedings. 2013. Available from: doi: 10.1063/1.4858736.

[43] Kelebek H, Selli S, Gubbuk H, Gunes E. Comparative evaluation of volatiles, phenolics, sugars, organic acids and antioxidant properties of Sel-42 and Tainung papaya varieties. Food Chemistry. 2015; 173: 912-919. 